\title{
Field Performance of False Horn Plantain (Musa AAB) Corms Treated Mechanically and with Hormone Solutions
}

\author{
J. Opata ${ }^{1, a^{*}}$, B.M. Dzomeku²,b S.K. Darkey"2,c, E. Opoku,d, R.K. Bam²,e \\ and J.-N. Wünsche ${ }^{1, f}$ \\ ${ }^{1}$ University of Hohenheim, Institute of Crop Science, Section Crop Physiology of Specialty Crops, \\ Emil-Wolff-Str. 25, 70599 Stuttgart, Germany
}

${ }^{2}$ CSIR-Crops Research Institute, P.O. Box 3785, Kumasi - Ghana, West Africa

Correspondence: johnopata@gmail.com,

Keywords: 6-benzylaminopurine, bunch, coconut water, macropropagation, seaweed extract, sucker

\begin{abstract}
The growth and yield performance of macropropagated plantlets of the False Horn plantain cultivar 'Apantu' was evaluated due to the lack of reliable data on the effectiveness of that planting material under typical farming conditions in West Africa, Ghana. Corms were either mechanically treated by the Plants Issus de Fragments de tige (PIF) technique to destroy the apical meristem or remained intact as untreated controls. Subsequently, PIF-treated corms were vacuum infiltrated with either natural or synthetic plant hormone solutions. Emerging plantlets were harvested, acclimatized for three months and planted in a freshly prepared field. Vegetative growth characteristics of each mother (main) plant were taken at 6 and 9 months after planting and for the main and first sucker crop along with yield parameters at harvest, respectively. The results indicated that treatment induced growth differences at 6 and 9 months after planting and were no longer significant at harvest. Consequently, final growth performance was quite homogenous across all treatments for the main and sucker crop, respectively. In contrast, fruit yield parameters of the main and sucker crops were to some extent affected by treatment; however, hormone infiltration tended to have little additional effect over the PIF-treatment. Nevertheless, treating corms with hormonal solutions enhanced the production of rooted plantlets at the nursery stage and ensured improved field performance.
\end{abstract}

\section{Introduction}

Plantain (Musa AAB) is an important food crop that is widely grown in the humid tropics of Africa, providing food for more than 70 million people in that region [1]. The majority of plantain production comes from rural families' backyard gardens as well as cultivated fields of smallholders and is an essential income source for resource poor farmers in developing countries [1], [2]. In West Africa, Ghana produces the largest plantain crop, which is of great socio-economic importance in terms of food security and job opportunity [3]. The demand for the 'cooking banana' is relatively high in both urban and rural communities and has resulted in an increased market price[4]-[6]. Consequently, many households have gradually expanded the field cultivation of plantain [4].

However, access to sufficient and inexpensive planting material by smallholder plantain farmers is a major constraint in Sub-Saharan Africa [5], [7], [8]. This is as a result of several factors, including low sucker production due to the apical dominance behaviour of the main pseudostem [1], [9], [10] and poor field management by smallholder farmers [11], [12]. Farmers often rely on young suckers or old corms directly from the field for the establishment of new plantings; however, this plant material is frequently infested with pathogens or various pests [8].

Therefore, several clonal propagation techniques have been developed to overcome the inadequate sucker production in plantain [13]-[16]. An innovative micropropagation technique for raising plantlets is tissue culture [17]-[20]; however, this procedure requires high initial investment costs for specialised laboratories. In contrast, a macropropagation technique that is now commonly employed by many smallholder plantain and banana farmers in Sub-Saharan Africa is the Plants Issus de Fragments de tige (PIF) treatment [13], [16], [21] that destroys the apical meristem with a 
crosswise incision and leads to robust and healthy plantlets at the nursery stage [5]. This is especially the case, when pest (e.g. banana weevil and nematodes) infested suckers and corms are treated with hot water at $52^{\circ} \mathrm{C}$ for 20 min prior to planting[11], [22]. Moreover, the PIF technique in combination with synthetic or natural plant growth regulators has increased the number of shoots per corm [21].

Despite several studies having demonstrated that large numbers of clean and healthy plantlets can be produced by macropropagation, there are only few data available on the performance of that planting material under typical farming conditions [23]. Therefore, the objective of this study was to assess the growth and yield performance of macropropagated plantlets. It is hypothesized, that suckers from corms manipulated with PIF and infiltrated with either natural or synthetic plant hormones had a better growth and yield performance than those from only PIF-treated corms.

\section{Materials and Methods}

Macropropagation of plantain plantlets was carried out at the Crops Research Institute (CRI) in Kumasi, Ghana, in 2016. Sword and ratoon sucker corms of the False Horn plantain cultivar 'Apantu' were harvested from an experimental plantation at the CRI. The corms were pared by removing roots before all leaf sheaths around the collar were carefully cut-off with a sharp knife that was frequently sterilized in $70 \%$ ethanol to reduce microbial contamination of the corms. The corms were then washed under running tap water to remove any foreign material. Air-dried corms were either mechanically manipulated by employing the PIF-technique or remained unchanged as an untreated control. PIF-treated corms were vacuum infiltrated with various aqueous solutions (Table 1) and planted in sterilized sawdust within a germination bed. The use of coconut water, seaweed extract and 6-benzylaminopurine as source of plant hormones followed an earlier study by [24]to assess the response of plantain to these hormones in terms of shoot proliferation. Moreover, these are the available sources of plant hormones smallholder farmers could access and employ to multiply plantains in the field.

Emerging plantlets were harvested and potted in 3-liter polyethylene bags, using soil that was sterilized with hot water steam for 3 hours. Potted plantlets were then acclimatized for three months under a shade structure constructed from palm fronds.

Table 1. Aqueous solutions used for vacuum infiltration of corms that were mechanically manipulated with the PIF-technique.

\begin{tabular}{|c|c|}
\hline Treatment & Complete description of treatment \\
\hline 1. $\mathrm{CW}_{\mathrm{f}}$ & fresh coconut water \\
\hline 2. $\mathrm{CW}_{\mathrm{a}}$ & autoclaved coconut water at $121^{\circ} \mathrm{C}$ for $15 \mathrm{~min}$ \\
\hline 3. $\mathrm{CWP}_{\mathrm{a}}$ & $\begin{array}{l}\text { coconut water with } 0.1 \%(\mathrm{w} / \mathrm{v}) \text { pulverized papain, incubated at } 40^{\circ} \mathrm{C} \text { for } 40 \mathrm{~min} \\
\text { and stirred every } 10 \mathrm{~min} \text { for } 1 \mathrm{~min} \text { and then autoclaved at } 121^{\circ} \mathrm{C} \text { for } 15 \mathrm{~min}\end{array}$ \\
\hline 4. $\mathrm{CW}_{\mathrm{a}} \mathrm{SW}$ & $\begin{array}{l}\text { autoclaved coconut water with } 0.5 \%(\mathrm{v} / \mathrm{v}) \text { of sea weed extract (Tecamin Raiz, } \\
\text { AgriTecno, Spain) }\end{array}$ \\
\hline 5. SW & $0.5 \%(\mathrm{v} / \mathrm{v})$ sea weed extract dissolved in distilled water \\
\hline 6. BAP & $\begin{array}{l}2.25 \mathrm{mg} \text { of 6-Benzylaminopurine (Carl Roth, GmbH, Germany), dissolved in } \\
1 \mathrm{~N} \mathrm{NaOH} \text { and diluted in } 1 \mathrm{~L} \text { of distilled water }\end{array}$ \\
\hline 7. $\mathrm{W}_{\mathrm{d}}$ & distilled water \\
\hline
\end{tabular}

\section{Experimental site}

A fallow that was not cultivated for about 10 years was selected for the field experiment at the CRI. Land preparation included clearing the sandy-loam (Arenosol) site from woody vegetation and mulching with the cuttings to improve soil fertility and water holding capacity[4], [25]. This type of land preparation is often recommended instead of the slash and burn approach [26], [27]. 
Acclimatized plants, each about $40 \mathrm{~cm}$ tall with 3-5 leaves, were selected from the nursery and planted in holes of $30 \mathrm{~cm}$ depth and $30 \mathrm{~cm}$ diameter at a spacing of $3 \times 2 \mathrm{~m}$ in the middle of the rainy season in July 2016[4], [28]. Each hole received $250 \mathrm{~g}$ well-decomposed poultry manure one week prior to planting.

The experimental site was fertilized in three split applications at 3, 6 and 9 months after planting with $170 \mathrm{~kg}$ urea $(46 \% \mathrm{~N}), 192 \mathrm{~kg}$ potassium chloride (approx. 50\% K) and $42 \mathrm{~kg}$ triple super phosphate $\left(46 \% \mathrm{P}_{2} \mathrm{O}_{5}\right)$ per hectare, respectively. Moreover, each plant received approximately $2 \mathrm{~kg}$ of cow dung prior to flowering. Weed control was carried out regularly either manually or by herbicide applications to ensure good plant growth and development. De-suckering of the main crop was performed at harvest to maintain two sword suckers and one ratoon sucker per plant mat.

\section{Experimental design and data collection}

The experimental set-up consisted of nine treatments each with 5-plant-plots assigned randomly to three replicated blocks, respectively. Vegetative growth parameters were taken for each mother (main) plant at 6 and 9 months after planting, respectively, and at harvest and of the first sucker crop (ratoon) at harvest: pseudostem girth at $50 \mathrm{~cm}$ above the soil line, pseudostem height from girth measuring point to the most recent unfolded upper leaf, and number of unfolded green leaves. Dead yellow-brownish leaves and leaves with more than $50 \%$ black sigatoka disease symptoms at the leaf surface were excluded. In addition, number of suckers were recorded for each plant mat at harvest of the main and sucker crop, respectively.

Crop phenology of both main and first sucker plants was evaluated by recording the number of months to flowering after planting and also days to fruit maturity from flowering. Moreover, yield performance was assessed by taking records of bunch weight, number of hands and fingers per bunch for each plant. Fruit maturity for the main plant started in September 2017 and that of the sucker plants in October 2018.

\section{Statistical analysis}

Analysis of variance (ANOVA) was used to evaluate the effect of mechanically manipulated and with varying aqueous solutions vacuum-infiltrated False Horn corms on pseudostem characteristics and yield performance. Data were analysed using Genstat $\left(18^{\text {th }}\right.$ Edition Rothamsted, United Kingdom) and displayed graphically with Microsoft Excel.

\section{Results}

\section{Crop phenology}

The timing of flowering after planting was not affected by the treatments and occurred between 13 and 15 months for the main crop and about 24 months for the sucker crop. Fruit maturity was reached for both crops between 90 and 105 days after flowering, irrespective of treatment.

\section{Growth characteristics of the main crop}

There was a significant treatment effect on pseudostem height at 6 and 9 months of plant growth in the field. Pseudostem height at 6 months after planting was on average $111 \mathrm{~cm}$ for $\mathrm{CW}_{\mathrm{f}}$ treated corms, followed by corms treated with BAP, which were $21 \%$ and $12.5 \%$ taller than those of PIFtreated corms (Table 2). At 9 months after planting, the highest pseudostems with about $158 \mathrm{~cm}$ were found by corms treated with $\mathrm{SW}$ and $\mathrm{CW}_{\mathrm{f}}$, which were about $11 \%$ longer than those of corms treated with BAP and the PIF-technique (Table 2). In contrast, there were no effects found at fruit harvest and average pseudostem height was at $2.9 \mathrm{~m}$ across all treatments.

There were no significant treatment effects on pseudostem girth at both growth stages. However, pseudostem girth tended to be with $29 \mathrm{~cm}$ in the $\mathrm{CW}_{\mathrm{f}}$ and with $43 \mathrm{~cm}$ in the $\mathrm{SW}$ treatment greater than in other treatments at 6 and 9 months after planting, respectively. At harvest, all treatments had a pseudostem girth of about $50.6 \mathrm{~cm}$. 
There were on average 8 and 10 green leaves per pseudostem at 6 and 9 months after planting with only small differences among the treatments (Table 2). $\mathrm{CW}_{\mathrm{a}} \mathrm{SW}$ produced with about 12 leaves per pseudostem significantly more leaves than any other treatment at 9 months of growth. At harvest, treatments had averagely 2 leaves per plant. The number of young suckers growing at harvest was not significantly affected by the treatment (Figure 1) and ranged between 3 and 4 shoots within the mat of the main crop.

Table 2. Effects of treatment (UTC - untreated control; PIF - Plant Issus de Fragments de tige; $\mathrm{CW}_{\mathrm{a}}$ - autoclaved coconut water; $\mathrm{CW}_{\mathrm{f}}$ - fresh coconut water; $\mathrm{CW}_{\mathrm{a}} \mathrm{SW}$ - autoclaved coconut water with seaweed extract; BAP - 6-benzylaminopurine; $\mathrm{CWP}_{\mathrm{a}}$ - coconut water with pulverized papain; $\mathrm{SW}$ seaweed extract; $\mathrm{W}_{\mathrm{d}}$ - distilled water) on vegetative growth characteristics of main plant pseudostem of False Horn plantain.

\begin{tabular}{lclll}
\hline \hline \multirow{2}{*}{ Treatment } & \multicolumn{3}{c}{6 month } & \multicolumn{1}{c}{9 month } \\
\cline { 2 - 5 } & Length (cm) & Leaf number & Length (cm) & Leaf number \\
\hline UTC & $84.5^{\mathbf{a}}$ & $8.1^{\mathbf{a b c}}$ & $127.1^{\mathbf{a b}}$ & $9.9^{\mathbf{a b}}$ \\
$\mathrm{PIF}$ & $87.5^{\mathbf{a}}$ & $8.2^{\mathbf{a b c}}$ & $137.7^{\mathbf{a b c}}$ & $10.5^{\mathbf{a b c}}$ \\
$\mathrm{CW}_{\mathrm{a}}$ & $87.3^{\mathbf{a}}$ & $7.3^{\mathbf{a}}$ & $119.6^{\mathbf{a}}$ & $9.5^{\mathbf{a}}$ \\
$\mathrm{CW}_{\mathrm{f}}$ & $110.6^{\mathbf{b}}$ & $8.8^{\mathbf{c}}$ & $156.8^{\mathbf{c}}$ & $10.9^{\mathbf{b c d}}$ \\
$\mathrm{CW}_{\mathrm{a}} \mathrm{SW}$ & $99.2^{\mathbf{a b}}$ & $8.3^{\mathbf{b c}}$ & $152.3^{\mathbf{b c}}$ & $11.9^{\mathbf{d}}$ \\
$\mathrm{BAP}$ & $100.0^{\mathbf{a b}}$ & $7.5^{\mathbf{a b}}$ & $142.1^{\mathbf{a b c}}$ & $9.9^{\mathbf{a b}}$ \\
$\mathrm{CWP}$ & $89.5^{\mathbf{a}}$ & $7.2^{\mathbf{a}}$ & $130.1^{\mathbf{a b}}$ & $9.6^{\mathbf{a b}}$ \\
$\mathrm{SW}$ & $96.0^{\mathbf{a b}}$ & $8.3^{\mathbf{b c}}$ & $159.0^{\mathbf{c}}$ & $11.7^{\mathbf{c d}}$ \\
$\mathrm{W}_{\mathrm{d}}$ & $88.3^{\mathbf{a}}$ & $7.9^{\mathbf{a b c}}$ & $141.7^{\mathbf{a b c}}$ & $9.4^{\mathbf{a}}$ \\
\hline Statistics & & & & \\
$\mathrm{P}_{\text {-value }}$ & $*$ & $*$ & $*$ & $* * *$ \\
LSD $_{0,05}$ & 16.1 & 1.1 & 25.6 & 1.4 \\
\hline
\end{tabular}

Data are means $(n=15)$ with different letters in the same column indicating significant difference at $\mathrm{p} \leq 0.05 . *$ and $* * *$ are significant at $\mathrm{p} \leq 0.05$ and $\mathrm{p}<0.001$, respectively.

\section{Growth characteristics of the sucker crop}

The pseudostem height and girth of the first sucker crop at harvest were not significantly affected by treatment. Plant height ranged between $3.2 \mathrm{~m}$ and $3.4 \mathrm{~m}$ across all treatments with an average girth of $63 \mathrm{~cm}$. There were 1-2 green leaves per plant at harvest. The number of young suckers grown within the mat of the first sucker crop at harvest was significantly affected by the treatment. BAP and SW had with averagely 3.3 suckers the highest number of all treatments (Fig. 1). 


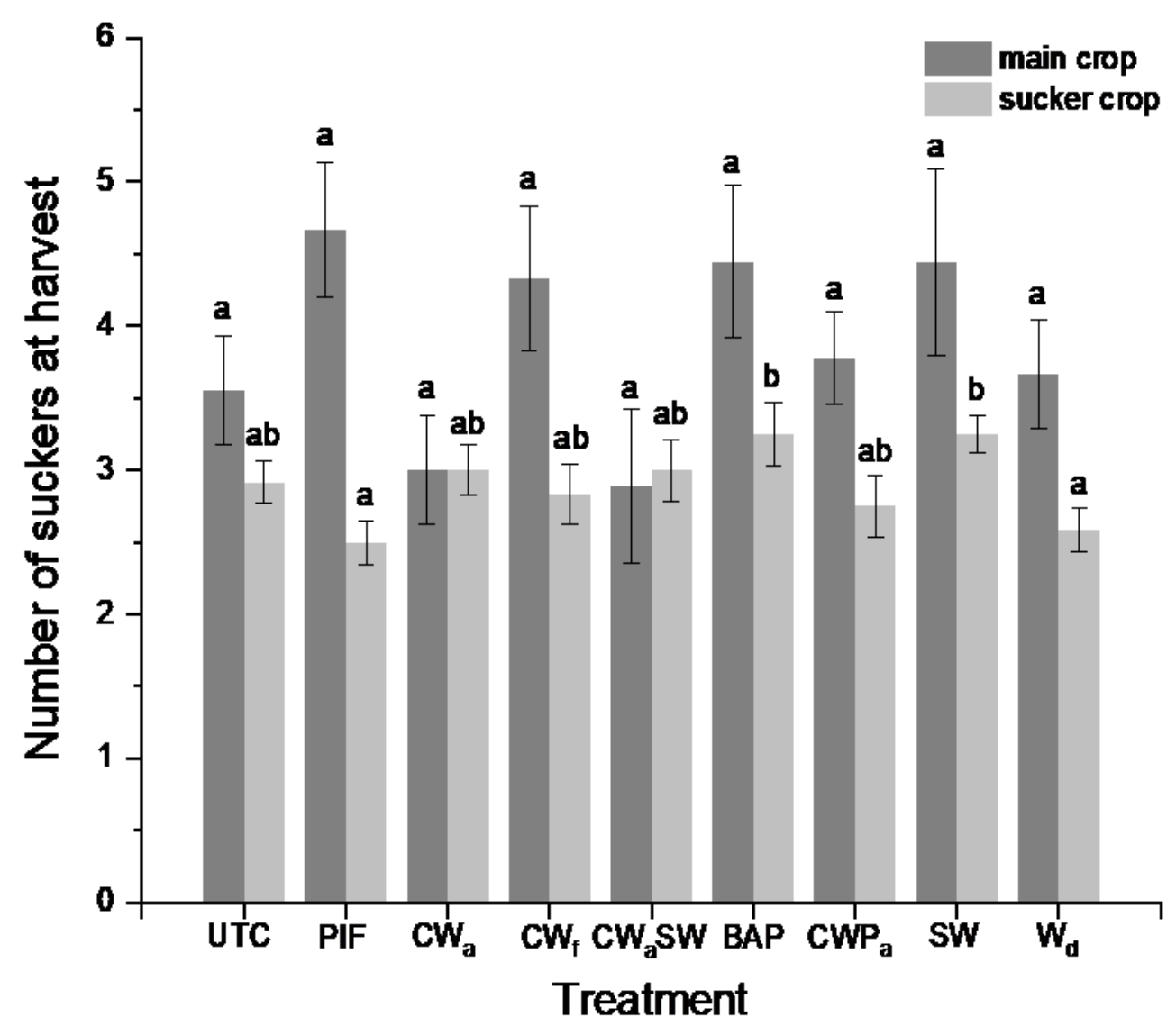

Figure. 1. Effects of treatment (UTC - untreated control; PIF - Plant Issus de Fragments de tige; $\mathrm{CW}_{\mathrm{a}}$ - autoclaved coconut water; $\mathrm{CW}_{\mathrm{f}}$ - fresh coconut water; $\mathrm{CW}_{\mathrm{a}} \mathrm{SW}$ - autoclaved coconut water with seaweed extract; BAP - 6-benzylaminopurine; $\mathrm{CWP}_{\mathrm{a}}$ - coconut water with pulverized papain; $\mathrm{SW}$ seaweed extract; $\mathrm{W}_{\mathrm{d}}$ - distilled water) on sucker production of the main and sucker crop, respectively, at harvest of False Horn plantain. Vertical bars indicate standard error of the means (main crop, $\mathrm{n}=9$ and sucker crop, $\mathrm{n}=12$ ) and different letters represent significant difference using LSD test at $\mathrm{P} \leq 0.05$.

\section{Yield performance of main and sucker crop}

Bunch weight of the main crop was significantly affected by treatment with the heaviest bunches of about $11 \mathrm{~kg}$ harvested of corms treated with BAP and SW (Table 3). Control plants $\left(\mathrm{W}_{\mathrm{d}}\right.$ ) produced the smallest bunches with $9.5 \mathrm{~kg}$. In contrast, bunch weight of the first sucker crop was similar across the treatments, yielding about $11 \mathrm{~kg}$ (Table 3).

There were no treatment effects on yield parameters of the main crop with averagely 6.4 hands per bunch and 29.6 fingers per bunch (Table 3). However, these yield parameters were significantly affected by treatment for the first sucker crop. Plants from corms treated with SW produced with 6.9 hands per bunch and 30.9 fingers per bunch the highest numbers, but in both cases was not significantly different from the PIF, BAP and $\mathrm{CW}_{\mathrm{f}}$ treatments, respectively (Table 3). 
Table 3. Effects of treatments (UTC - untreated control; PIF - Plant Issus de Fragments de tige; $\mathrm{CW}_{\mathrm{a}}$ - autoclaved coconut water; $\mathrm{CW}_{\mathrm{f}}$ - fresh coconut water; $\mathrm{CW}_{\mathrm{a}} \mathrm{SW}$ - autoclaved coconut water with seaweed extract; BAP - 6-benzylaminopurine; $\mathrm{CWP}_{\mathrm{a}}$ - coconut water with pulverized papain; SW seaweed extract; $\mathrm{W}_{\mathrm{d}}$ - distilled water) on yield characteristics of main and sucker crops, respectively, of False Horn plantain.

\begin{tabular}{|c|c|c|c|c|c|c|}
\hline \multirow[t]{2}{*}{ Treatment } & \multicolumn{2}{|c|}{ Yield (kg/bunch) } & \multicolumn{2}{|c|}{ Hands per bunch } & \multicolumn{2}{|c|}{ Fingers per bunch } \\
\hline & Main Crop & $\begin{array}{l}\text { Sucker } \\
\text { Crop }\end{array}$ & Main Crop & $\begin{array}{l}\text { Sucker } \\
\text { Crop }\end{array}$ & Main Crop & $\begin{array}{l}\text { Sucker } \\
\text { Crop }\end{array}$ \\
\hline UTC & $10.7^{b c}$ & $10.9^{\mathrm{a}}$ & $6.3^{\mathrm{a}}$ & $6.3^{\mathrm{a}}$ & $29.3^{\mathrm{a}}$ & $28.9^{a b}$ \\
\hline PIF & $10.4^{b c}$ & $11.0^{\mathrm{a}}$ & $6.4^{\mathrm{a}}$ & $6.4^{\mathrm{abc}}$ & $28.1^{\mathrm{a}}$ & $29.7^{a b c}$ \\
\hline $\mathrm{CW}_{\mathrm{a}}$ & $10.7^{b c}$ & $11.0^{\mathrm{a}}$ & $6.6^{\mathrm{a}}$ & $6.4^{\mathrm{abc}}$ & $29.4^{\mathrm{a}}$ & $28.9^{\mathrm{ab}}$ \\
\hline $\mathrm{CW}_{\mathrm{f}}$ & $10.7^{b c}$ & $11.1^{\mathrm{a}}$ & $6.6^{\mathrm{a}}$ & $6.7^{a b c}$ & $32.1^{\mathrm{a}}$ & $30.5^{c}$ \\
\hline $\mathrm{CW}_{\mathrm{a}} \mathrm{SW}$ & $10.0^{\mathrm{ab}}$ & $10.8^{\mathrm{a}}$ & $6.3^{\mathrm{a}}$ & $6.3^{\mathrm{ab}}$ & $29.6^{\mathrm{a}}$ & $28.8^{a b}$ \\
\hline BAP & $11.3^{\mathrm{c}}$ & $11.0^{\mathrm{a}}$ & $6.6^{\mathrm{a}}$ & $6.8^{b c}$ & $28.1^{\mathrm{a}}$ & $30.0^{b c}$ \\
\hline $\mathrm{CWP}_{\mathrm{a}}$ & $9.8^{\mathrm{ab}}$ & $10.9^{\mathrm{a}}$ & $6.4^{\mathrm{a}}$ & $6.2^{\mathrm{a}}$ & $30.2^{\mathrm{a}}$ & $28.2^{\mathrm{a}}$ \\
\hline SW & $11.0^{\mathrm{c}}$ & $11.4^{\mathrm{a}}$ & $6.1^{\mathrm{a}}$ & $6.9^{\mathrm{c}}$ & $29.6^{\mathrm{a}}$ & $30.9^{c}$ \\
\hline $\mathrm{W}_{\mathrm{d}}$ & $9.4^{\mathrm{a}}$ & $10.8^{\mathrm{a}}$ & $6.4^{\mathrm{a}}$ & $6.2^{\mathrm{a}}$ & $29.1^{\mathrm{a}}$ & $28.3^{\mathrm{a}}$ \\
\hline \multicolumn{7}{|l|}{ Statistics } \\
\hline P-value & $*$ & ns & ns & $*$ & ns & $*$ \\
\hline $\operatorname{LSD}_{0.05}$ & 0.9 & 0.4 & 0.6 & 0.5 & 3.1 & 1.5 \\
\hline
\end{tabular}

Data are means (main crop $n=9$; sucker crop $n=12$ ) with different letters in the same column indicating significant difference at $\mathrm{p} \leq 0.05 . *$ is significant at $\mathrm{p} \leq 0.05$; ns: not significant.

\section{Discussion}

Growth and yield performance of plantain plants derived from Plants Issus de Fragments de tige, which is currently and widely employed by smallholder plantain farmers in West and Central Africa, has not been intensively studied. In contrast, this technique in combination with hormone applications, has been thoroughly evaluated for its potential on the rate of shoot proliferation. However, smallholder farmers are aiming to achieve high yields for securing their livelihood through product sales and thus income generation. Consequently, this study investigated the effect of plantain corms treated with PIF and hormone solutions on the growth and yield performance of both the main crop and the first sucker crop.

The lack of treatment effect on the number of suckers of the main crop might be due to all plantlets having developed sufficient roots during the nursery and acclimatization phase [29]. It has been suggested by [30] that vigorous growth and high suckering ability is the results of a strong root system rather than carry-over effect from corms treated with growth hormones. Moreover, the main crop from corms treated with the PIF-technique and hormone solutions, particularly $\mathrm{CW}_{\mathrm{f}}$, had longer psuedostems than those that were only mechanically manipulated. This has also been described for in-vitro plantain plants, which were significantly taller when treated with growth hormones [18]. The generally stronger growth of the first sucker crop compared to the main crop was also reported by [31] and might be attributable to the application of manure [32] in combination with the regular fertilizer.

The plantain cultivar used in the current trial is a landrace, which is susceptible to black Sigatoka, a fungal disease caused by Mycosphaerella fijiensis [33]. [34] reported that all landrace plantain cultivars are susceptible to the black Sigatoka disease with detrimental effects on leaf production [18]. In the current study little to none leaf pruning was employed to control the disease.

The time of flowering and fruit maturity of the cultivar 'Apantu' could not be altered with hormone and fertilizer applications. Nevertheless, the slightly longer time to flowering after planting of the main crop from PIF-treated corms was reported earlier by [35]. The average bunch weights are comparable to those reported in other studies with the same cultivar [36], [37]. However, the sucker crop generally recorded heavier bunch weights than the main crop. Similar findings were reported by 
[38], demonstrating bigger bunches in the ratoon crops than their respective mother crops. In summary, it should be emphasized that good management practices of plantain fields are imperative for attaining high yield [36].

\section{Conclusions}

The study demonstrated that both main and sucker plantain crops from hormonally treated corms did not significantly perform better than those from only PIF-treated corms in most of the growth and yield parameters. However, yield performance also depends on good agronomic practices in the field. In contrast, treating corms with growth hormones is highly relevant at the propagation stage to raise robust plantlets with high numbers of roots for improving their field performance. Moreover, the PIF-technique is a reliable low cost option for smallholder farmers to enhance the proliferation rate of the source material in the nursery.

\section{Conflict of Interest}

The authors declare no conflict of interest.

\section{Acknowledgments}

We are grateful for the financial support provided by the German Federal Ministry for Education and Research for the GlobE Biomass Web research project (FKZ 031A258E). We also acknowledge supplementary financial support by Fiat Panis through the Food Security Centre at the University of Hohenheim. Finally, much appreciation goes to the technicians of the plantain and banana division of the Crops Research Institute, Kumasi, Ghana, who extensively supported the field work.

\section{References}

[1] R. Ortiz and D. R. Vuylsteke, Genetics of apical dominance in plantain (Musa spp., AAB group) and improvement of suckering behavior, Journal of the American Society for Horticultural Scieince. 119 (5) (1994) 1050-1053.

[2] R. Nkendah and E. Akyeampong, Socioeconomic data on the plantain commodity chain in West and Central Africa, Info Musa. 12 (2003) 8-13.

[3] B. M. Dzomeku et al., Improving crop protection on banana farms in Ghana, Acta Horticulturae. 828 (2009) 389-394.

[4] R. Swennen, Plantain cultivation under West African conditions : A reference manual, 1990.

[5] L. M. Lefranc et al., Macropropagation as an innovative technology: Lessons and observations from projects in Cameroon, Acta Horticulturae. 879 (2010) 727-734.

[6] K. Tomekpe et al., CARBAP and innovation on the plantain banana in Western and Central Africa, International Journal of Agricultural. Sustainability. 9 (1) (2011) 264-273.

[7] B. Faturoti et al., Rapid multiplication of plantain and banana: macropropagation techniques. International Institute of Tropical Agriculture. (2002) 1-10.

[8] M. R. Kasyoka et al., Evaluating the macropropagation efficiency of banana varieties preferred by farmers in Eastern and Central Kenya: In Second RUFORUM Biennial Meeting, Entebbe, Uganda. (2010) 499-503.

[9] D.M. Macias, In situ mass propagation of the FHIA-20 banana hybrid using benzylaminopurine, Infomusa. 10 (1) (2001) 3-4.

[10] E. Langford et al., An evaluation of banana macropropagation techniques for producing pig fodder in Northern Thailand, Sustainable Agriculture Research. 6 (2) (2017) 48-57. 
[11] S. Hauser, Effects of fertilizer and hot-water treatment upon establishment, survival and yield of plantain (Musa spp., AAB, French), Field Crops Research. 66 (3) (2000) 213-223.

[12] A. Tenkouano et al., Clean planting materials and management practices for sustained production of banana and plantain in Africa, Chronica Horticulturae. 46 (2) (2006) 14-18.

[13] M. Kwa, Activation of latent buds and use of banana stem fragments for the in vivo mass propagation of seedlings, Fruits. 58 (2003) 315-328.

[14] J. K. Osei, Rapid field multiplication of plantains using benzyl adenine or coconut water-treated split corms, Ghana Journal of Agricultural Science. 39 (2) (2006) 189-202.

[15] J. N. Buah et al., The effects of different concentrations cytokinin on the in vitro multiplication of plantain (Musa sp.), Biotechnology. 9 (3) (2010) 343-347.

[16] B. M. Dzomeku et al., Response of selected local plantain cultivars to PIBS (Plants Issus De Bourgeons Secondaires) technique, Journal of Plant Development. 21 (2014) 117-123.

[17] R. A. Drew and M. K. Smith, Field evaluation of tissue-cultured bananas in south-eastern Queensland, Australian Journal of Experimental Agriculture. 30 (1990) 569-574.

[18] D. R. Vuylsteke and R. Ortiz, Field performance of conventional vs. in vitro propagules of plantain (Musa spp., AAB group), HortScience. 31 (5) (1996) 862-865.

[19] J. N. Buah et al., Field performance of in vitro-propagated and sucker-derived plants of banana (Musa spp.), Plant Production Science. 3 (2) (2000) 124-128.

[20] B. Niere et al., Performance of tissue-cultured versus sucker-derived East African highland banana (Musa AAA-EA) under high and low input systems in Uganda, Field Crops Research. 156 (2014) 313-321.

[21] G. V Kindimba and T. J. Msogoya, Effect of benzylaminopurine on in vivo multiplication of French plantain (Musa spp. AAB ) cv . 'Itoke sege,' Journal of Applied Biosciences. 74 (2014) 6086-6090.

[22] A. Hauser et al., On-farm demonstration , testing and dissemination of ' boiling water treatment' for plantain (Musa spp.) sucker sanitation in Southern Cameroon, Acta Horticulturae. 879 (2010) 509-516.

[23] L. Norgrove and S. Hauser, Improving plantain (Musa spp. AAB) yields on smallholder farms in West and Central Africa, Food Security. 6 (4) (2014) 501-514.

[24] J. Opata et al., Macropropagation of plantain (Musa AAB): Responses to hormonal and mechanical corm manipulation, Fruits, International Journal of Tropical and Subtropical Horticulture. 75 (3) (2020) 123-129.

[25] M.N. Tswanya et al., Influence of mulch material and mulching rate on fruit yield and microorganisms of tomato variety ( Lycopersicon lycopersicum mill ) in Ogbomosho and Mokwa, Nigeria, Advances in Biotechnology and Microbiology. 6 (3) (2017) 1-9.

[26] V. Smil, Crop residues : Agriculture's largest harvest, Bioscience. 49 (4) (1999) 299-308.

[27] C. Giardina et al., The effects of slash burning on ecosystem nutrients during the land preparation phase of shifting cultivation, Plant and Soil. 220 (1) (2000) 247-260.

[28] B. M. Dzomeku et al., Comparative study on the field performance of FHIA-01 ( hybrid dessert banana) propagated from tissue culture and conventional sucker in Ghana, Journal of Plant Development. 19 (2012) 41-46.

[29] D. Coyne et al., Boiling water treatment: A simple, rapid and effective technique for nematode and banana weevil management in banana and plantain (Musa spp.) planting material, Crop Protection. 29 (12) (2010) 1478-1482. 
[30] M. K. Smith et al., Comparison between micropropagated banana (Musa AAA; 'Williams') and conventional planting material during the first 12 months of development, Journal of Horticultural Science and Biotechnology. 76 (1) (2001) 83-87.

[31] G. Blomme, R. Swennen, and A. Tenkouano, Root system development during two crop cycles in banana and plantain (Musa spp.), Acorbat. 15 (2002) 418-424.

[32] B. Eghball, D. Ginting, and J. E. Gilley, Residual effects of manure and compost applications on corn production and soil properties, Agronomy Journal. 96 (2) (2004) 442-447.

[33] B. M. Dzomeku et al., Sensory evaluation of some cooking bananas in Ghana, Journal of Applied Sciences. 6 (4) (2006) 835-837.

[34] A. O. Olaleye et al., Influence of potassium fertilizer on yield of plantain intercropped with cassava on an Oxic paleustalf in southwestern Nigeria, Communication in Soil Science and Plant Analysis. 37 (2006) 925-938.

[35] C. Mekoa and S. Hauser, Survival and yield of the plantain 'Ebang' (Musa spp., AAB Genome, 'False Horn') produced from corm fragment initiated plants and suckers after hot water treatment in Southern Cameroon, Acta Horticulturae. 879 (2010) 527-535.

[36] A. A. Shaibu, E. A. Maji, and M. N. Ogburia, Yield evaluation of plantain and banana landraces and hybrids in humid agro ecological zone of Nigeria, Journal of Agricultural Research and Development. 2 (3) (2012)74-79.

[37] B. M. Dzomeku et al., Evaluating postharvest characteristics of Apantu (Local False Horn) plantain for harvest indices determination, International Journal of Plant Physiology and Biochemistry. 8 (1) (2016) 1-6.

[38] J. C. Obiefuna, The effect of monthly planting on yield, yield patterns and yield decline of plantains (Musa AAB), Scientia Horticulturae (Amsterdam). 29 (2) (1986) 47-54. 